\title{
Cyber Space and Virtual Reality
}

\section{Ozan Adam, Bahcesehir University, Turkey}

\begin{abstract}
The central focus of my literature review is on the cyber space, culture, virtual reality, identity, and artificial intelligence in relation to the media, consumer society and the masses. The visualization of the stories of the books is one of the concepts that will be explored and another major topic discussed in the literature review is based on the perception of time and work in relation to the crafts and the techniques involved in the cinema industry, the production of the video games and the concepts and the transforming notions of time, reality, simulation of the experience of real time in cinema by exploring the influence of the editing and the recreation of time and the sense of reality with the help of the high technology, digital computer generated graphics, editing and special effects especially after the all-encompassing "digital revolution". As the technological developments open new doors to alternative ways of communication, marketing, interaction, and existence with the progressions made on the telecommunication, the inter-net, virtual reality, cyberspace and culture, the hypothetical science fiction themes became a part of the reality of the modern society.
\end{abstract}


Interestingly many of the books I reviewed were books which were adapted into films later on and one of the marketing strategies that are very obvious is that fact that the imagery such as the posters, stills and the visualization technique of the films were incorporated into the books as well. The covers of some of the books had the visuals of the films. This is an important issue because the majority of the public identify the book with the movie but the book demands more of the attention, creativity and the imagination of the reader and on the contrary the films do the work of interpreting the text for the spectator by adapting the story, excluding certain parts, visualizing and editing. Therefore the relationship of the reader to a book compared to the audience to a film has very intrinsic in terms of the way in which the media, the product or the information is transmitted and perceived. As the technology advances newer forms of media such as cinema and video games begin to dominate and they replace the older original forms of communication as in the case of the books discussed.

The scholarly resources of my work is based on the books, articles, studies and researches of Karl Marx, Engels, Theodor Adorno, Max Horkheimer, Marshall McLuhan, Andre Bazin, Gilles Deleuze, Roland Barthes, Richard Sennett, John Berger, Walter Benjamin, Slavoj Zizac, David Mamet, David Fintcher and David Lynch.

The structure of the literature review will address specific examples of science fiction novels some of which have been adapted into films such as the books by Philip K. Dick, "Do Androids Dream of Electric Sheep?" (1968) which was adapted into a film titled Blade Runner by Ridley Scott in 1982, "Minority Report”, (1956), which was made into a move with the same title by Steven Spielberg in 2002, "We Can Remember It for You Wholesale", (1966), which was adapted into film titled Total Recall by Paul Verhoeven in 1990, “A Scanner Darkly", (1977) by Philip K. Dick was also produced as a movie with the same title directed by Richard Linklater in 2006, "I, Robot" (1950) by Isaac Asimov which was adapted into a film by the same title by Alex Proyas in 2004, The story of "Nightfall", (1941), by Isaac Asimov was adapted on radio programs Dimension X and X Minus One in the 1950s and was produced as a movie directed by Jacques Tourneur in 1957 and it was produced with the same title Nightfall in 2000 by Gwyneth Gibby, "Solaris" written by Stanislaw Lem (1961) was adapted into a film by the same title by Andrei Tarkovsky in 1972 and later by Steven Soderbergh in 2002, "Neuromancer" (1984 ) by William Gibson which was inspired by 
Escape from NY 1981 directed by John Carpenter and the book has parallel stories with movie The Matrix directed by Larry Wachowski and Andy Wachowski in 1999.

The common thesis of most of the works examined in the literature review concentrates on the human perception and its transformation in the futuristic vision of the authors. Simulation, cyberspace, virtual reality, robotics and the structure of the society in relation to the architecture, culture, economics, ideology and politics are very crucial common elements in the stories and they have very close connections to paradigms and phenomena discussed by Karl Marx, Friedrich Engels, Theodor Adorno, Max Horkheimer, Marshall McLuhan, Andre Bazin, Gilles Deleuze, Roland Barthes, Richard Sennett, John Berger, Walter Benjamin, Jacques Lacan, Slavoj Zizek and Jean Baudrillard.

The future of the world portrayed in the books and the films that are based on the novels illustrate a very clear picture of the society and the individual in the cultural, social, political and economic system, which have very illuminating parallel aspects of the modern society, media and existence. The similarities between the reality of the $21^{\text {st }}$ century and the stories of the books are very clear and the fact that the genre of the stories and books are categorized as science fiction makes one wonder about the metaphoric and direct connections between the reality of the modern industrial, consumer oriented, capitalist, imperialist, global corporate systems of today and the fictitious works which are "science fiction" because they appear to have a lot in common. It almost seems like we are living in a science fiction world. The idea of the dominant mechanical and over powering system in the society forcing and controlling the minds of the people exist both in the theoretical psychology, cultural, media studies and the science fiction works. "The novel titled "Neuromancer" (1984) written by William Gibson which is his first novel and the beginning of the "Sprawl" trilogy and the winner of the Nebula Award, the Philip K. Dick Award, and the Hugo Award tells the story of a washed-up computer hacker hired by a mysterious employer to work on the ultimate hack. Gibson explores artificial intelligence, virtual reality, genetic engineering, and multinational corporations overpowering the traditional nation-state long before these ideas entered popular 
culture. The concept of cyberspace makes its first appearance, with Gibson inventing the word to describe "a consensual hallucination experienced daily by billions."”,

The movie titled The Matrix has been inspired and influenced by the story of this novel and there is a film project that is based on the story of this book, which is going to be produced in 2009. McLuhan has discussed the idea of the simulation of reality. Marshall Mc Luhan points out the important elements and the effects of the media in his preliminary researches and focuses on the different kinds of media categorized as the hot / cold and the high resolution / low resolution qualities of the media by examining the intensity of the influences these kinds of modern communication methods have on the audiences and ultimately on the thinking patterns, behaviours consumption and the perception of reality of the masses. He addresses the issue of the transmitted information through different sources and how the communities receive the information. The terms of the signifier, signified and the myth come up in his writings in the earlier stages and later he draws attention to the crucial aspect of media formulating a certain hierarchy and system of ethics and refers to the mechanisms involved in the manipulation of the thought processes on the receiver side. When the medium requires

\footnotetext{
${ }^{1}$ Retrieved from, http://en.wikipedia.org/wiki/Neuromancer Gibson, W. (1984). Neuromancer. (pp. 5). New York: Ace Book Publishing Inc.
}

\begin{abstract}
“Case was twenty-four. Twenty-two, he'd been a cowboy, a rustler, one of the best in the Sprawl. He'd been trained by the best, by McCoy Pauley and Bobby Quine, legends in the biz. He'd operated on an almost permanent adrenaline high, a byproduct of youth and proficiency, jacked into a custom cyberspace desk that projected his disembodied consciousness into the consensual hallucination that was the matrix."
\end{abstract}

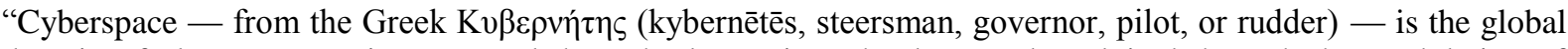
domain of electro-magnetics accessed through electronic technology and exploited through the modulation of electromagnetic energy to achieve a wide range of communication and control system capabilities. The term is rooted in the science of cybernetics and Norbert Weiner's pioneering work in electronic communication and control science, a forerunner to current information theory and computer science. Through its electro-magnetic nature, cyberspace integrates a number of capabilities (sensors, signals, connections, transmissions, processors, controllers) and generates a virtual interactive experience accessed for the purpose of communication and control regardless of a geographic location. In pragmatic terms, Cyberspace allows the interdependent network of information technology infrastructures (ITI), telecommunications networks--such as the Internet, computer systems, integrated sensors, system control networks and embedded processors and controllers common to global control and communications. As a social experience, individuals can interact, exchange ideas, share information, provide social support, conduct business, direct actions, create artistic media, play simulation games, engage in political discussion, etc. The term was originally coined in the cyber-punk genre of science fiction author, William Gibson. The now ubiquitous term has become a conventional means to describe anything associated with computers, information technology, the internet and the diverse internet culture." Retrieved from, http://en.wikipedia.org/wiki/Cyberspace
} 
more senses to be involved in the interaction, the medium becomes more like reality. The involvement of multiple senses in the medium stimulates the senses and therefore the medium in a sense transforms into a new kind of reality or a simulation of it. High level of engagement in a medium is described as hot medium but with the technological advances in media some of the hot and cold qualities of all medium have changed. The medium becomes more like reality when all or most senses are triggered in the participation so therefore high definition is an important factor for the degree of simulation and stimulation. If the medium can be also examined from another perspective, the categorization of the media as a medium just as described in McLuhan's "Medium is the message" as any other form of technology can be analyzed in terms of its influence on the daily practices, behaviours and consumption of individuals and its effects on the time and space of the participants in the society. As the medium becomes more influential on the society, it gets hotter and increases the level and scale of social transformation. This matter is emphasized in the chapter titled "Media Hot and Cold in Understanding Media" in The Extension of Man written by Marshall McLuhan in 1964.

A lot has changed since the 1960"s in terms of the technology used in the mass communication industries, networks and the social structure of the societies regarding to the ideologies and the socio economic and political agendas in the last decade. Therefore some of McLuhan's analysis and arguments do not precisely fit the specific developments such as the computer, the cyber and the digital environment of today yet his general intellectual critical approach that is inherent in his statements still reveal a great deal of clues to the infrastructures and the mechanisms involved in mass media and cultural transformations.

The concept of simulation of reality is a phenomenal subject. It has very strong roots in the development of image formation and cinema, which have evolved into massive industries. The power of the image and the reproduction of it have changed the way people experience time, space and therefore reality. It is exactly the same impact that made the spectators run away from the front rows of the movie theatre when the Lumiere Brother first projected the train approaching the platform of the train station. The audience could not distinguish the image of the train from the real material of the train. The issue of simulation became a sensational phenomenon in the $20^{\text {th }}$ century as studied and discussed by many intellectuals, 
scholars and industry specialists. Cybernetics, semiology and simulation are the central terms that operate on the human senses and they determine the essential stimulants and their perceptual, cognitive, cultural and ideological effects. These fundamentals of communication are directly and indirectly discussed by Gilles Deleuze in his book "Cinema" published in 1986 and the book titled "Gilles Deleuze's Time Machine" written by David Norman Rodowick who reflects on the ideas of Gilles Deleuze and the functions and structures that are embraced by the potentials of cinema as a medium. The order of signs, symbols, icons, images and the social sciences which studies the mechanisms of semiotics, cybernetics and virtual reality opens new doors to the interpretation of imagery in the movies as well as they do in many fields of study such as psychology, sociology and philosophy.

The audio / visual strength of the moving image has redefined the terminology and the bases of the studies concentrating on the experience of reality. John Johnson also makes references to the norms and concepts discussed by Gilles Deleuze in his article titled "Abstract Machines and New Social Spaces" written in 2008. He elaborates on a theoretical framework within which four examples of the virtual reality novel are examined. The framework draws on Pierre Levy's book "Becoming Virtual” (1998), as well as philosophical discussions of the concept of the virtual in writings by Henri Bergson, and Gilles Deleuze and Felix Guattari. In contrast to the opposition between the possible and the real, the dynamic of the virtual is understood as a potential power or agency actualized in a process that can change the basis of our current notions of reality."2

\footnotetext{
${ }^{2}$ Johnston J. (2008). Abstract Machines and New Social Spaces: The Virtual Reality Novel and the Dynamic of the Virtual. Information, Communication \& Society, 11.6, 749-764. doi: 10.1080/13691180802010683
}

(Biography: John Johnston, Professor of English and Comparative Literature at Emory University in Atlanta, Georgia, is author of Carnival of Repetition, Information Multiplicity, and The Allure of Machinic Life. He also edited and introduced Literature, Media, Information Systems, a collection of essays by the German media theorist Friedrich Kittler, and has published many essays on contemporary media theory and culture. He is currently at work on Computer Fictions, a book about literature and philosophy in the age of network culture. Affiliation: Department of English, Emory University, Atlanta, GA, USA)

\begin{abstract}
"This essay elaborates a theoretical framework within which four examples of the virtual reality novel are examined. The framework draws on Pierre Leacutevy's book, Becoming Virtual (1998), as well as philosophical discussions of the concept of the virtual in writings by Henri Bergson, and Gilles Deleuze and Felix Guattari. In contrast to the opposition between the possible and the real, the dynamic of the virtual is understood as a potential power or agency actualized in a process that can change the basis of our current notions of reality. More specifically, the essay suggests that the material operations of today's computer technology are the source
\end{abstract}


The movies titled Strange Days (1995) directed by Kathryn Bigelow and eXistanZ directed by David Cronenberg in 1999 also focus on the idea of virtual reality where the invention of specific devices enable individuals to experience themselves in different realities. As written about in books and adopted into the films and in designed virtual video games; the memories and emotions of individuals can be replaced by another person and the idea of transforming and transporting identity, the individualistic personal feelings, fantasies and memories become an important issue in the arguments of Slavoj Zizek in "The Sublime Object of Ideology", "Interrogating The Real" and "Looking Awry" as well as in many others such as “The Art of Ridiculous Sublime On David Lynch's Lost Highway". John Johnson also makes references to the norms and concepts discussed by Gilles Deleuze in his article titled "Abstract Machines and New Social Spaces" written in 2008. He elaborates on a theoretical framework within which four examples of the virtual reality novel are examined.

The virtual cyber space enables the reality and the emotional and physical experiences to be artificially transformed and transported from one person to another or the virtual reality can be designed, programmed and executed without exchanging data between individuals which is a familiar situation that the masses and the audiences unconsciously or consciously experience and practice in cinema and also in other forms of media. In other words the media facilitates the simulation and functions as the generator of new codes and visual imagery as hallucinations for the masses. The individuals as a part of the consumption patterns of the audiences in the modern societies are transformed into passive receivers of the messages filled with economic, political, social, ideological and cultural codes that are being transmitted by the global corporate companies which also own the media companies as mentioned by Walter Benjamin, McChesney and Smythe in their work and analyses.

of this virtual power and that we can see how it is variously represented in the virtual reality novel. While each of the four novels depicts living or acting within virtual reality spaces, they differ markedly in how these experiences are integrated into larger narrative concerns, which include the decoding and recoding of the human body, cultural identity, sexuality and control, and the new apparatuses of surveillance and communication this technology will soon bring about." Retrieved from, http://www.informaworld.com/smpp/content content=a902407307 db=all order=page 
"A portmanteau of simulated stimuli, simstim is a technology whereby a person's brain and nervous system is stimulated to simulate the full sensory experience of another person. Simstim is usually used as a form of entertainment, whereby recordings of simstim stars in soap operas are transmitted in effect replacing television. However, simstim also has other uses; Case is connected to Molly via simstim during the Panther Modern's attack on Sense/Net. In this way, simstim was used as a sophisticated method of communication although the signal was one-way."3

The terms used in the book "Neuromancer" make references to many interesting concepts and gadgets, which draw attention to the similarities of the technical and technological phenomena of today in a metaphorical or direct way in some cases.

The virtual and the cyber space, the artificial interaction and experiences replace the real space / time, reality and the real (the physical, social interaction) and experiences in the social structures dominated by the media. The TV, radio, printed media and the computer create a predetermined, designed, formulated and fabricated virtual / cyber space where the spectators are physically passive receivers and they are only active mentally and there is a minimal level of physical activity involved. The masses are entertained, amused, kept mentally occupied and busy and physically and socially passive, manipulated, controlled, monitored and hypnotized by the media so that draws attention to the similar situation explained in "Neuromancer" and The Matrix and this is very much in conjunction with the arguments of McLuhan, Richard Sennett, Gilles Deleuze, Theodor W. Adorno, Horkheimer, Smythe and McChesney, yet many aspects of the theoretical subject matter is not entirely pointed out, explored or analyzed in connection to the futuristic vision and predictions depicted by the perspective of the thesis of the science fiction books. The similarities and parallel discoveries, criticisms observations and visions of the scholarly research, analysis made by the philosophers, scholars and the works of science fiction writers clarify the potentials that are not entirely pursued in media studies. This overlapping and common interest of the theoretical, cultural media studies and the science fiction genre present an important area of study that has not been entirely examined therefore it embraces a great potential. The future envisioned by the science fiction

\footnotetext{
${ }^{3}$ Retrieved from, http://en.wikipedia.org/wiki/Neuromancer\#Film projects
} 
books has a lot in common with the media studies scholarly research topics and arguments. The lack of academic research in this specific area is quite a crucial missing element in the criteria of the critical, cultural, media studies. The shared views, credentials, areas of interest of the academic research and the science fiction literature inhabit fundamental intellectually critical phenomena and paradigms because both scholars, scientists and science fiction authors concentrate on arguments that are based on the technological, political, ideological, social and cultural norms, systems and structures and their transformations in time. Therefore there is clearly a relevantly independent objective perspective in both the scholarly research and the work of the science fiction authors because they observe the present situation, the political, ideological, socio-economic and the technological, scientific developments and their effects on the masses in order to draw conclusions or make hypothetical predictions, to present the dynamics of the determinant elements in the social systems by focusing on their economic implications, structural order, political hegemony and the cultural patterns. This intersection of the conceptual approaches of the academic, fictitious and the scientific endeavours both in science fiction and scholarly research has not been thoroughly realized. 


\section{References}

Adorno, T.,\& Horkheimer, M. (1944). Dialectic of Enlightenment. New York: Social Studies Association, Inc.

Asimov, I. (1941). Nightfall. New York: Bantam Spectra Books Ltd.

Barthes, R. (1968). Elements of Semiology. New York: Hill and Wang.

Deleuze, G. (1983). Cinema 1 \& 2: The Movement Image, The Time Image.

Paris: Les Éditions de Minuit.

Dick, P. K. (1956). Minority Report. New York: Pantheon Books Ltd.

Dick, P. K. (1966). We Can Remember It for You Wholesale. London: Orion Books Ltd.

Dick, P. K. (1968). Do Androids Dream of Electric Sheep?. London: Orion Books Ltd.

Dick, P. K. (1977). A Scanner Darkly. New York: Pantheon Books Ltd.

Engels, F. (1883). Dialectics of Nature. New York: International Publishers Co.

Foucault, M. (1982). This Is Not A Pipe. Berkeley, CA: University of California Press.

Gibson, W. (1984). Neuromancer. New York: Ace Book Publishing Inc.

Horkheimer, M. (1947). Eclipse of Reason. New York: Oxford University Press.

Mamet, D. (1997). Make-Believe Town: Essays and Remembrances. Boston, Cambridge: Back Bay Books.

Lem, S. (1961). Solaris. London: Faber and Faber Ltd.

Lem, S. (1964). Summa Theologiae (Sum of Technology). Frankfurt: Suhrkamp Verlag KG

Lem, S. (1967). The Cyberiad. Fort Washington, PA: Harvest Books Company LLC.

Lem, S. (1987). Fiasko. Frankfurt: Suhrkamp Verlag KG.

Zizek, S. (1989). The Sublime Object of Ideology. London and New York: Verso Press.

Zizek, S. (2006). Interrogating the Real. London: Continuum Press.

Zizek, S. (1992). Looking Awry: An Introduction to Jacques Lacan through Popular Culture. Cambridge, MA: The MIT Press. 